\title{
Innovative construction technology for the development of urban space
}

\author{
Oksana Kurakova ${ }^{1, *}$ \\ ${ }^{1}$ Moscow State University of Civil Engineering, Yaroslavskoye sh., 26, Moscow, 129337, Russia
}

\begin{abstract}
The use of innovative technologies in construction contributes to the development of the urban environment. Reduction of construction time allows more intensive development of the territory, as well as to reduce the period of inconvenience to citizens associated with construction. Such intensification is possible due to the development of organizational and technological concepts aimed at reducing the time of finished products output while ensuring their high quality and efficient use of all types of resources involved in the construction process. So, the achieved results in the field of introduction of continuous-flow type of operation, reducing work labor input and increasing the intensity of labor have created a high potential for cast-in-place construction of buildings at a speed comparable with the use of prefabricated reinforced concrete technology. Despite this, the analysis of various situations connected with the cast-in-place reinforced concrete construction has shown that in most cases, the actual investment period completion dates for such projects take much longer than planned. This fact has a very negative impact on the cost of construction. A characteristic feature of the cast-in-place reinforced concrete construction is the circumstance that such a situation can be observed even at an advanced level of organizational management when the conditions for the continuity of supplies of materials, highly mechanized work and the scheduled provision of the production process with qualified labor resources are held. The comprehensive analysis conducted during the research of the organization of construction showed that an essential drawback of modern approaches to the organizational management in the case of cast-in-place construction is the excessive conservatism of methods that does not ensure the proper speed of making managerial decisions in the event of deviations in execution of certain works. The author conducted and presents an analysis of the factors influencing the efficiency of high-rise construction. 3resented directions of further actions to improve the efficiency of construction and reduce its time frame.
\end{abstract}

\section{Introduction}

The cast-in-place construction technology has been among top priority construction methods for many years. This type of high-rise construction makes it possible to erect

\footnotetext{
*Corresponding author: ks-home@mail.ru
} 
buildings based on various design concepts, while providing a wide range of architectural and urban development opportunities [1].

The construction of residential buildings using cast-in-place technology was put into practice in Germany a little less than a hundred years ago. Since the second half of the 20th century, these technologies have been widely used in Europe and especially in the USA. As concerns Russia, construction of residential monolithic houses began intensively only in the early 90's. To date, the share of cast-in-place concrete produced in Russia has come very close to those of the countries leading in the economic and industrial sectors (Figure 1) [2, $3]$.

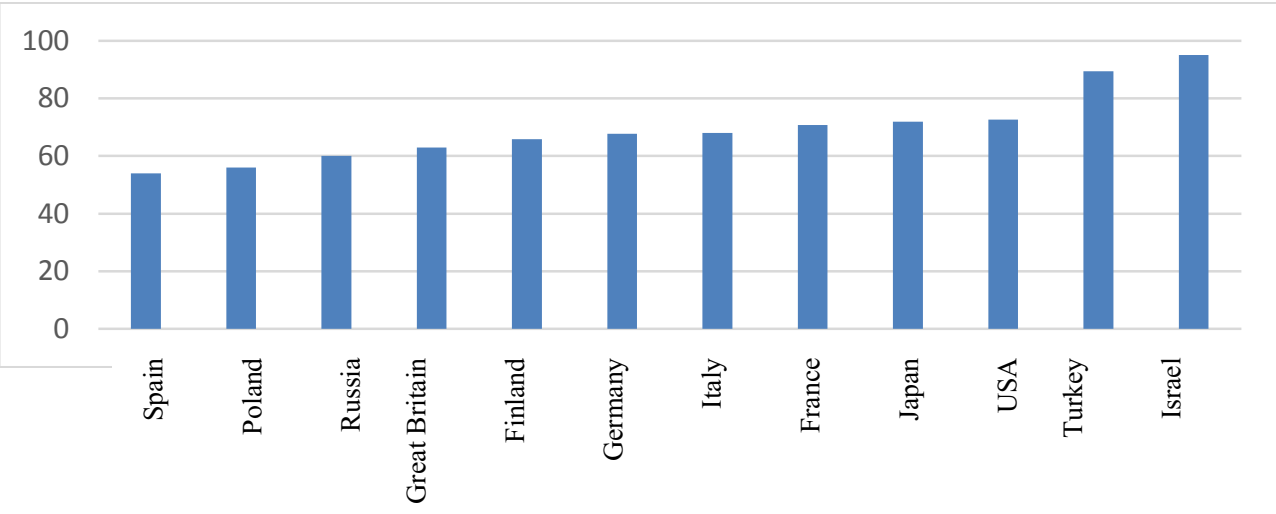

Fig. 1. Share of cast-in-place concrete construction in various countries, 2016.

In Russia, the transition to cast-in-place construction and its further development were due to three main factors:

1. physical depreciation of the existing precast reinforced concrete base (in connection with the economic situation at that time);

2. appearance of foreign companies in the domestic construction market (mostly in Moscow) that were well-versed in the cast-in-place technology and had all the necessary equipment;

3. changing stereotypes of Russian society, which no longer accepted the typification and utilitarian nature of architectural forms.

According to the studies conducted in Russia, there is a tendency of an annual increase in the volume of cast-in-place construction. This is due to the following undeniable advantages of this technology:

1. the full life of buildings and structures made of cast-in-place reinforced concrete is in the order of 100-150 years, and the design features of the material enable it to withstand an earthquake with a magnitude of up to 9;

2. higher structural resistibility and strength of buildings and facilities;

3. the customer-specific facade of each building;

4. reduction of the consumption of materials (concrete and steel) due to a more complete use of the advantages of continuous systems;

5. absence of structural joints and seams, that increases sound and dust impermeability of the premises;

6. less stringent standardization of space-planning parameters of buildings, facilities, and stand-alone structures.

\section{Materials and methods}


During cast-in-place construction, in most cases, the actual investment period completion dates for such projects take much longer than planned. This fact has a very negative impact on the cost of construction.

To solve this problem, an integrated approach to optimizing the organizational and technological concepts of the cast-in-place process is needed. The cast-in-place construction process consists of several technologically connected and consistently performed works (Figure 2):

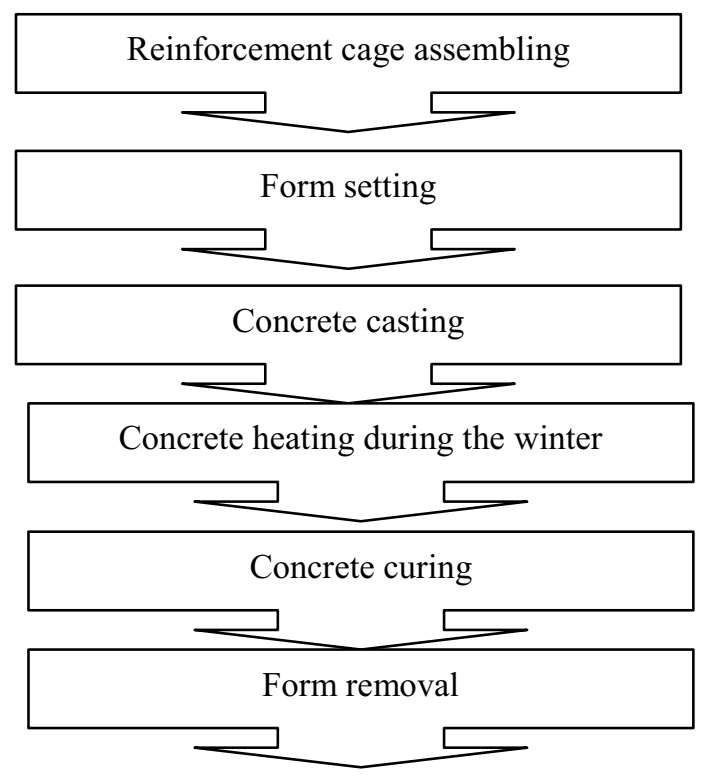

Fig. 2. The sequence of cast-in-place high-rise construction works.

It is expedient to carry out research in the following directions:

Analysis of ways to increase the efficiency of implementation of cast-in place investment and construction projects;

Improvement of technology and organization of the main types of work (formwork, reinforcement, concrete) through the introduction of new organizational and technological concepts;

Technical and economic assessment of the developed organizational and technological concepts.

At the same time, it is necessary to take into account the factors affecting the efficiency of the project implementation (Figure 3) [4]. 


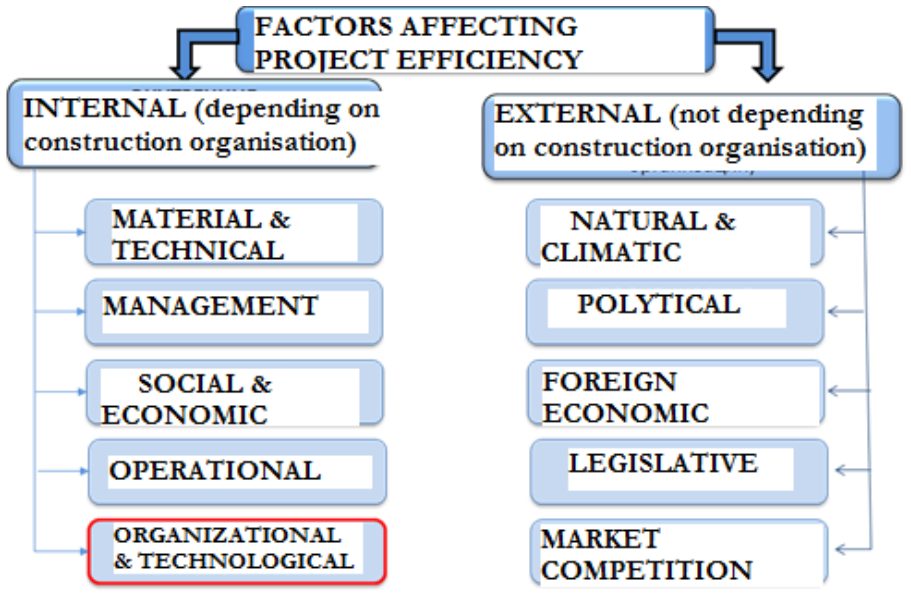

Fig. 3. Factors affecting the efficiency of high-rise construction projects.

\section{Results}

The most significant factors in terms of cost and duration of construction are organizational and technological ones.

The necessary conditions for improving the organizational and technological solutions for the implementation of cast-in-place development projects are: the updating all-up mechanized technologies, the use of high-capacity specialized machinery and equipment, the increase in the share of the use of machines and mechanisms in relation to manual labor share, the involvement of competent specialists with the adequate level of education and further training of employees $[5,6]$.

The principal organizational \& technological factors:

- Peculiarities of construction concepts;

- Assembling and type of concrete forms;

- Concrete placement and curing;

- Specialty of teams of workers;

- Quality and quantity of construction equipment and machinery;

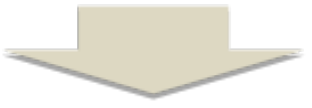

- Development of labor productivity due to sustainable use of work labor, equipment \& machinery;

- Reduction of construction costs;

- Reduction of time period for investment construction project implementation;

Fig. 4. Organizational and technological factors affecting the efficiency of the cast-in-place investment and high-rise construction project.

The improvement of organizational and technological concepts for the implementation of developer's cast-in-place projects makes it possible to increase both the speed of the 
building erection and the volume of construction. All this leads to the increase in the personnel wage fund, the emergence of new vacant jobs and the improvement of the standard of living of citizens as a whole. It also gives a possibility in short terms, to provide the population with the necessary housing and develop infrastructure within the city programs $[7,8]$.

An equally important factor in optimizing cast-in-place works is attraction of skilled personnel who are able to solve the most complex technological plans and tasks. In order to master new approaches and advanced technologies, further training of employees is needed.

If all the recommendations for optimization and improvement of the organizational and technological concepts are adhered to, it is possible to achieve high speed of work, to reduce labor input, to enhance the quality of the finished product and to use all types of resources efficiently.

\section{Conclusion}

Analysis of the current condition and directions of the development of cast-in-place reinforced concrete construction showed that the technology in question has been already widely used in domestic construction projects and has the best prospects for its further development. However, there are a number of open issues related to the high labor intensity and the share of manual labor in the construction processes, the low skill level of workers, lack of normative documents on cast-in-place construction, and the underdevelopment of production management systems and quality control of works and facilities in general.

As a result of review of the main trends in the development of cast-in-place construction, the expediency of transition to this type of construction has been shown.

Based on the analysis of domestic and foreign experience in cast-in-place construction, the main factors influencing the efficiency of investment and construction projects have been identified [9-12]

To implement the technology of cast-in-place construction, the need to update the organizational and technological concepts (reinforcing, formwork and concrete work) has been revealed. The results of these studies will be presented in subsequent projects.

\section{References}

1. A.K. Orlov, MATEC Web of Conferences 08013, 106 (2017)

2. A.K. Orlov, I.Y. Chubarkina, MATEC Web of Conferences 08015, 106 (2017)

3. V. Telichenko, Vestnik MGSU 12(4), 364-372 (2017)

4. A.P. Chan, D.W. Chan, U.H. Chiang, B.S. Tang, E.H. Chan, K.S. Ho, Journal of Construction Engineering and Management 130(2), 188-198 (2004)

5. J. Pelletier, C. Alt, C. Parr, J. Farrell T. Farrell, Proceedings of the Unified International Technical Conference on Refractories UNITECR, 15-20 (2013)

6. D. Lucius, Journal of Property Investment and Finance 19, 73-78 (2001)

7. D. Bakhshi, A. Touran, Procedia Engineering 85, 52-60 (2014)

8. S. Mokhlesian, M. Holmen, Construction Management and Economics, 30(9) (2012)

9. C. Tam, V. Tam, W. Tsui, International Journal of Project Management 22(7) (2004)

10. H. Feng, K. Hewage Energy and Buildings 75, 281-289 (2014)

11. H. Jang, S. Choi, W. Kim, C. Chang, KSCE Journal of Civil Engineering 16(7), 1115 1122 (2012)

12. O. Alshamrani, K. Galaland, S. Alkass Building and Environment 80, 61-70 (2014) 